\title{
Os médicos como elos entre a ciência e a prática*
}

\author{
Doctors as links between science and practice
}

Los médicos como eslabón entre la ciencia y la práctica

Precisaria a linguagem de uma poetisa para dizer a dimensão do meu agradecimento à equipe do Conselho Regional de Medicina do Estado do Pará (CRM-PA) por ter me escolhido como representante dos médicos, designando com meu nome a semana comemorativa de nossa profissão.

Meditando sobre os motivos dessa distinção, recordo as palavras de Manoel Soares, em seu editorial Constituindo elos, para a Revista Pan-Amazônica de Saúde', ao se referir àqueles que participam das diferentes etapas do conhecimento. Considerando-se que, hoje, a prática médica vive a medicina baseada em evidências, o médico está tão relacionado com a ciência que alguns autores, quando querem enfatizar a contribuição desta no bem-estar da humanidade, citam os avanços da medicina para medir o progresso da civilização.

Carl Sagan, em seu livro $O$ mundo assombrado pelos demônios ${ }^{2}$, afirma que a eficiência da medicina moderna permitiu que a expectativa da vida humana, que era de 30 anos ao final do Império Romano e na Idade Média, atingisse 50 em 1915, e chegasse em 1990 a aproximadamente 80 anos. Esses resultados - consequência de revoluções sem precedentes na biologia, manifestadas na biologia celular e molecular, associadas ao desenvolvimento de outras ciências - permitiram o florescimento de uma indústria com impacto não só na medicina, tornando-a extremamente complexa, mas também na agricultura e em outras atividades humanas. Daí a necessidade de elos para a junção da realidade sanitária com o ambiente, tanto no campo teórico como no empírico, na busca de novos conhecimentos e nas tentativas de aplicá-los às atividades rotineiras de saúde pública.

Em toda a minha vida profissional, que não considero ainda acabada, tenho procurado servir de elo em dois sentidos. Primeiramente, trazendo a experiência do médico sanitarista, com vivência na medicina curativa e preventiva por oito anos contínuos nas áreas rurais do Estado do Pará, para a pesquisa epidemiológica no Instituto Evandro Chagas (IEC), como membro do Belém Virus Laboratory, cujo principal objetivo era o estudo dos arbovírus. Essa experiência ajudou na abordagem dos sujeitos da pesquisa, para a obtenção das informações e dos espécimes biológicos necessários tanto nas pesquisas de cunho etiológico, quanto nos inquéritos de incidência e prevalência entre os habitantes da Amazônia.

Em outro sentido, atuei levando o conhecimento e a tecnologia mais recentes para as atividades rotineiras da saúde pública. Como exemplo das ações nesse âmbito, relato as atividades pioneiras, ainda usando os testes de imunodifusão e imunoeletrosmoforese no auxílio aos bancos de sangue na triagem dos doadores de sangue; e, com o desenvolvimento do Ministério da Saúde, ao serem criados os laboratórios centrais nas secretarias estaduais de saúde, auxiliando a implantação do diagnóstico sorológico das hepatites virais nesses laboratórios, na Amazônia. Ainda como exemplo do elo nesse sentido, as atividades de maior impacto imediato vincularam-se à participação na execução e estudos da vacinação contra a hepatite B. A primeira foi iniciada em 1989, em Boca do Acre, em conjunto com outros 12 municípios do Estado do Amazonas onde estudos já haviam demonstrado a alta letalidade da infecção pelos vírus das hepatites B e delta. $O$ objetivo era vacinar $80 \%$ das crianças com menos de 10 anos de idade, com uma vacina de DNA recombinante desenvolvida havia pouco na França e nos Estados Unidos.

O planejamento, a coordenação, os estudos de imunogenicidade, a implantação na rotina do Programa Nacional de Imunizações naquele município no mesmo ano e o estudo da eficácia por mais cinco anos couberam a mim, auxiliada pela equipe da Seção de Hepatologia do IEC da qual o dr. Manoel Soares já fazia parte. Essa equipe também se envolveu na aplicação da vacina junto com os técnicos da Secretaria Municipal de Saúde de Boca do Acre. A segunda foi a participação no estudo multicêntrico sobre a imunogenicidade e segurança da vacina Butang desenvolvida e produzida pelo Instituto Butantan, de São Paulo, com a tecnologia de engenharia genética, cujos estudos das fases iniciais haviam se mostrado promissores.

\footnotetext{
* Discurso proferido em 19 de outubro de 2015 por ocasião da Semana do Médico "Dra. Gilberta Bensabath", promovida pelo Conselho Regional de Medicina do Estado do Pará, Brasil.
} 
estudo duplo-cego, com vacina Engerix como padrão, teria que abranger todas as idades em que deveria ser aplicada na rotina, e foi realizado no Rio de Janeiro, Recife e Belém, tendo sido recrutadas perto de 4 mil pessoas, das quais 2.754 cumpriram todos os critérios do protocolo ao final do estudo. Em Belém, foram estudados $61,9 \%$ do total com 11 a 40 anos de idade, incluindo-se toda a parte laboratorial desses sujeitos. Após esse estudo e outros que se lhe seguiram, a vacina Butang entrou no calendário vacinal do Ministério da Saúde.

Também não fiquei indiferente às mudanças nas atividades de rotina da saúde pública brasileira ocorridas nas décadas de 1980 e 1990. A vigilância epidemiológica, após a implantação da Lei n 8.080/1990³ e as profundas modificações decorrentes - entre essas, a vigilância com base de notificações de doenças que, apesar de existir desde 1975, eram mais realizadas à base de serviços verticalizados -, bem como a criação dos laboratórios de saúde pública estaduais, levaram as autoridades de saúde federais a conceber, dentro da estrutura administrativa do IEC, uma interface de vigilância e laboratório, cuja implantação, desde o planejamento e coordenação de suas atividades, coube-me de 2000 até 2012. Reconhecendo a complexidade da saúde pública, introduzi nos estudos epidemiológicos - não só de surtos, como nos de avaliação de saúde (endemicidade), relacionados às doenças transmissíveis - a metodologia da abordagem sindrômica, a qual inclui a multidisciplinaridade e a interdisciplinaridade.

Portanto, para mim, ser um elo faz parte de ser médico. Siqueira, em seu artigo Repensando a arte de ensinar a ciência da vida ${ }^{4}$, afirma que desde a Antiguidade, e mesmo entre os povos indígenas, os praticantes da arte de curar eram respeitados principalmente por seu compromisso com as necessidades de seu grupo; e que ao lado da competência técnica e científica havia um compromisso com o humanismo e a ética.

Todavia, em determinada altura, algo começou a mudar. As mudanças coincidiram com o veloz avanço científico e tecnológico do século XX e levaram à demanda por especialização, com crescente valorização da propedêutica armada em detrimento do raciocínio clínico. Concomitantemente, cresceram os custos da atenção médica, sem uma correspondente melhoria no atendimento, verificando-se até mesmo sua desumanização. $\bigcirc$ pior é que, muitas vezes, o setor de atenção médica passou a ser culpabilizado por crises cuja causalidade não lhe caberia diretamente, a exemplo da falta de médicos em áreas de difícil acesso ou da chamada crise da saúde pública, observada mesmo em países desenvolvidos, devido ao desajuste entre o discurso e a prática.

Hoje, quando se faz obrigatório repensar não só as práticas como a formação médica, em que devem figurar como base os cuidados fundamentados no humanismo e na ética, devido à imensa complexidade técnico-científica dessas atividades, cada vez mais é exigida a multidisciplinaridade e, portanto, segundo Morin ${ }^{5}$, a ligação dos saberes. Enfim, todos nós médicos devemos agir e prosseguir como elos.

\author{
Gilberta Bensabath \\ Editora Científica da Rev Pan Amaz Saude \\ Instituto Evandro Chagas/SVS/MS, Ananindeua, Pará, Brasil
}

\title{
REFERÊNCIAS
}

1 Soares MCP. Constituindo elos. Rev Pan-Amaz Saude. 2013 dez;4(4):9.

2 Sagan C. O mundo assombrado pelos demônios. São Paulo: Companhia das Letras; 1996.

3 Brasil. Lei $n^{\circ}$ 8.080, de 19 de setembro de 1990. Dispõe sobre as condições para a promoção, proteção e recuperação da saúde, a organização e o funcionamento dos serviços correspondentes e dá outras providências. Diário Oficial da União, Brasília, p. 18055, 20 set. 1990. Seção 1.

4 Siqueira BP. Repensando a arte de ensinar a ciência da vida. In: $29^{\circ}$ Congresso Brasileiro de Educação Médica; 2001 ; Belém - PA. Rio de Janeiro: Associação Brasileira de Educação Médica; 2001. p. 7-8.

5 Morin E. A religião dos saberes: o desafio do século XXI. Rio de Janeiro: Bertrand Brasil; 2007. 